\title{
Orvosok kiégettségének összefüggése az egészséggel, életérzéssel, alváskörülményekkel
}

\author{
Németh Anikó Dr. \\ Szegedi Tudományegyetem, Egészségtudományi és Szociális Képzési Kar, \\ Egészségmagatartás és -fejlesztés Szakcsoport, Szeged
}

\begin{abstract}
Bevezetés: A kiégés gyakran előforduló jelenség az egészségügyi dolgozók, így az orvosok körében is. Célkituzés: A kiégés esetleges összefüggésének feltárása az egészséggel, pszichoszomatikus tünetekkel, életérzéssel, alváskörülményekkel. Módszer: Kvantitatív keresztmetszeti vizsgálat online kérdőívvel 186 orvos részvételével. A kiégés mérésére Pines és Aronson 21 tételből álló kérdéssorozatát alkalmazta a szerző. Az adatok típusainak megfelelően $\chi^{2}$-próbát, független kétmintás T- és Mann-Whitney-tesztet, korrelációanalízist végzett a szerző. A kiégés stresszorainak vizsgálata lineárisregresszió-analízissel történt. Eredmények: A kiégés mértéke negatívan korrelált az életkorral $(\mathrm{p}=0,040 ; \mathrm{r}=-0,151)$, az egészségügyben eltöltött évek számával $(\mathrm{p}=0,027 ; \mathrm{r}=-0,162)$, a pozitív jólléttel $(\mathrm{p}<0,001, \mathrm{r}=-0,670)$, és pozitívan korrelált a negatív jólléttel $(\mathrm{p}<0,001 ; \mathrm{r}=0,585)$, az élettel való elégedettséggel $(\mathrm{p}<0,001 ; \mathrm{r}=-0,532)$. A burnout által érintettek rosszabbnak ítélték meg egészségi állapotukat $(\mathrm{p}<0,001)$, gyakrabban jelentkeztek pszichoszomatikus tünetek $(\mathrm{p}<0,001)$, daganatos $(\mathrm{p}=0,007)$, allergiás $(\mathrm{p}=0,030)$, pszichiátriai $(\mathrm{p}=0,025)$ megbetegedések és alvászavar. Következtetések: A kiégés a válaszadó orvosok egyharmadát érinti; a magasabb életkor és a több gyermek protektív tényezőnek bizonyult. Orv. Hetil., 2016, 157(16), 623-630.
\end{abstract}

Kulcsszavak: orvosok, kiégés, egészség, pszichoszomatikus tünetek, jóllét

\section{Burnout among doctors and its correlations with health, life satisfaction and sleep}

Introduction: Burnout is common among health care providers and doctors. Aim: The correlations between burnout and health, psychosomatic symptoms, life satisfaction and sleep were investigated. Method: An online quantitative cross-sectional questionnaire was administered to 186 doctors. Burnout was assessed by the means of the 21 -item questionnaire of Pines and Aronson (1981). Data were analysed with chi-square probe, Mann-Whitney test, correlational analysis and linear regression. Results: Level of burnout correlated negatively with age $(\mathrm{p}=0.040 ; \mathrm{r}=-0.151)$, years spent in the health care system $(\mathrm{p}=0.027 ; \mathrm{r}=-0.162)$ and positive well-being $(\mathrm{p}<0.001, \mathrm{r}=-0.670)$, while there was a negative correlation with negative well-being $(\mathrm{p}<0.001 ; \mathrm{r}=0.585)$ and life satisfaction $(\mathrm{p}<0.001 ; \mathrm{r}=$ $-0.532)$. Doctors with burnout reported worse health $(\mathrm{p}<0.001)$, more frequent psychosomatic symptoms $(\mathrm{p}<0.001)$, tumours $(\mathrm{p}=0.007)$, allergies $(\mathrm{p}=0.030)$, psychiatric disorders $(\mathrm{p}=0.025)$ and sleep disturbances. Conclusions: One-third of the doctors were affected by burnout in the present study. Higher age and having more children served as a protective factor.

Keywords: physicians, burnout, health, psychosomatic disorders, well-being

Németh, A. [Burnout among doctors and its correlations with health, life satisfaction and sleep]. Orv. Hetil., 2016, $157(16), 623-630$.

(Beérkezett: 2016. február 2.; elfogadva: 2016. február 25.)

A kiégés jelenségét egészségügyi dolgozók körében $\mathrm{Her}$ bert Freudenberger írta le 1974-ben [1]. Krónikus érzelmi megterhelés, stressz hatására fellépő érzelmi, fizikai, mentális kimerülés, amelyre jellemző a reménytelenség, céltalanság. Az orvosi hivatásban gyakori jelenség a stressz, amely hozzájárulhat pszichés és szomatikus betegségek kialakulásához [2]. Egy Ausztriában végzett felmérés szerint minden harmadik orvost érint a kiégés 
valamilyen foka [3]. Shanafelt és mtsai megállapították, hogy az orvosok 30-65\%-a kiégett, amely erősen függ a szakterülettől. A sürgősségi ellátásban és a belgyógyászaton dolgozók a leginkább érintettek [4], a nemek megoszlását tekintve pedig kifejezetten a nók veszélyeztetettek [5]. A burnout szoros összefüggést mutat az egészség rossz megítélésével [6], a munkahelyen megélt stresszel [7], megnöveli a munkahely elhagyásának esélyét [8], rontja a betegekkel való kapcsolat minőségét [9].

Több hazai kutatás is vizsgálta már az orvosok kiégését, valamint szomatikus egészségét. Ádám és mtsai reprezentatív felmérésükben azt találták, hogy a kiégés 40 év alatti és házas orvosok körében gyakoribb, valamint szoros összefüggést mutat a szubjektív egészségi állapot rossz megítélésével, az allergiás, izom- és csontrendszeri betegségek, valamint a pánikbetegség és alvászavar kialakulásával [10]. Ugyancsak ők számoltak be a magyar családorvosok magas pszichés morbiditásáról [11]. Györffy és Girasek szintén a fiatalabb orvosok körében tapasztalta leginkább a burnout jelenségét, valamint a fekvőbetegellátásban dolgozók körében. A saját gyermekek védő tényező szerepét is bizonyították [12]. Papp és Túry pályakezdő orvosok körében magas prevalenciájú kiégést mutattak ki [13]. Orvosok esetében a kiégés egyik következménye lehet, hogy kevesebbszer keresik fel betegeiket a betegágynál [14], romlik a betegellátás minősége [15], valamint gyakoribbá válnak a múhibák [16].

Az orvosok kiégését vizsgáló hazai kutatások a Maslach Burnout Inventoryt alkalmazták, amely a kiégést három dimenzióban (emocionális kimerülés, cinizmus, teljesítménycsökkenés) méri [17]. Ezt a mérőeszközt akkor alkalmazzák inkább, amikor az egyes komponensek önmagukban történő vizsgálata is fontos [18]. A kiégés mértékének, előfordulási gyakoriságának vizsgálatára alkalmazható Pines és Aronson 21 tételból álló kérdéssorozata [19], amelyet eddig Magyarországon még nem alkalmaztak orvosokkal kapcsolatos felmérésekben, de egészségügyi szakdolgozók, ápolók vizsgálatában már többször mérőeszközök részét képezte [20-24]. Vizsgálatom célja volt feltárni az orvosok kiégettségének mértékét Pines és Aronson [19] kérdéssorozata alapján, és megvizsgálni annak esetleges összefüggését az egészséggel, pszichoszomatikus tünetekkel, életérzéssel, alváskörülményekkel.

\section{Módszer}

A kvantitatív keresztmetszeti vizsgálat 2015. októberdecember hónapokban történt egy saját szerkesztésű online kérdőívvel, amely az egészségi állapotra, gyógyszerszedési szokásokra, káros szenvedélyekre vonatkozó kérdéseken túl tartalmazta a kiégés [19], az egészségi állapot szubjektív megítélésére szolgáló skálát [25], a kortársakhoz viszonyított egészség értékelésére szolgáló skálát [26], a pszichoszomatikus tüneti skálát [27], a jóllétet [28] és az élettel való elégedettséget [29] vizsgáló kérdéseket is. A mérőeszközt több, orvosokat tömö- rítő közösségi oldalon, e-mailen keresztül, valamint a WebDoki hírlevelének és a Magyar Orvosok Szövetségének segítségével terjesztettem. A 193 beérkezett válaszból 186 bizonyult értékelhetőnek. Hét válaszadó kizárása történt nem orvosi végzettség, illetve dupla válaszadás miatt.

Az adatelemzést IBM SPSS 22.0 for Windows statisztikai programmal, $\chi^{2}$-próbával (nominális adatoknál), független kétmintás T-teszttel (F-próbával), korrelációanalízissel (intervallumskálán mért adatok esetén) és Mann-Whitney-teszttel (ordinális változók esetén) végeztem. A kiégés stresszorainak vizsgálatára lineárisregresszió-analízist alkalmaztam. A szignifikancia kritériumhatára $\mathrm{p}<0,05$.

\section{Eredmények}

A válaszadó 186 fó 66,7\%-a nő, 33,3\%-a férfi, átlagéletkoruk 51,14 év (medián = 53; SD = 12,93; minimum = 25 ; maximum $=82$ ). Vas megye kivételével mindenhonnan érkeztek válaszok. A Pest megyeiek teszik ki a válaszadók 27,4\%-át, a Csongrád megyeiek 21\%-át, a többi megyéből $1,1-8,6 \%$ a válaszadók megoszlása, illetve négy külföldön élő orvos is kitöltötte a kérdőívet. A fogorvosok száma (7 fó) elenyésző a mintában. A családi állapotot tekintve $62,4 \%$ házas, $13,4 \%$ egyedülálló, $9,1 \%$ él kapcsolatban, 7,5\% elvált, 4,8\% élettársi kapcsolatban él, 2,7\% özvegy. Az egészségügyben átlag 26,63 éve dolgoznak $($ medián $=29 ; S D=13,43 ;$ minimum = 1 hónap; maximum $=57$ év).

A burnout vizsgálatára szolgáló 21 kérdést [19] 1-7ig lehetett pontozni ( 1 = soha, 2 = egyszer vagy kétszer, $3=$ ritkán, $4=$ néha, $5=$ gyakran, $6=$ általában, $7=$ mindig), a skála megbízható (Cronbach- $\alpha=0,902)$. A kiégés mértékét egy képlet segítségével kellett meghatározni, majd az így kapott átlagpontszám alapján csoportosítani a válaszadókat az alábbi négy csoportba: „örökös eufória” ( 1,9 pont alatt; a válaszadók $25,3 \%$-a), „jól csinálja” (2-2,9 pont; a válaszadók 37,1\%-a), „változtatás szükséges” (3-3,9 pont; a válaszadók 14,5\%-a), „kezelés szükséges” (4 pont felett; a válaszadók 23,1\%-a). A „változtatás szükséges" csoportba tartozók esetében már jelentkeznek a kiégés tünetei, a „kezelés szükséges” csoport tagjai már kiégetteknek tekinthetők.

A kiégés átlagpontszámának összefüggését különböző folytonos változókkal, korrelációanalízissel vizsgáltam. A korrelációs mátrix eredménye alapján megállapítható, hogy a kiégés mértéke negatívan korrelál az életkorral $(\mathrm{p}=0,040 ; \mathrm{r}=-0,15 \mathrm{l})$ és az egészségügyben eltöltött évek számával ( $\mathrm{p}=0,027 ; \mathrm{r}=-0,162)$.

A burnout négy kategóriáját dichotomizáltam: a "nincs kiégés” csoportba soroltam az „örökös eufória” és a „jól csinálja” csoportba tartozókat (116 fö; 62,4\%); a „kiégettek" csoportjába pedig a másik két csoportba sorolt válaszadókat, ők valamilyen mértékben már érintettek a kiégés által (70 fő; 37,6\%). A továbbiakban ezen 


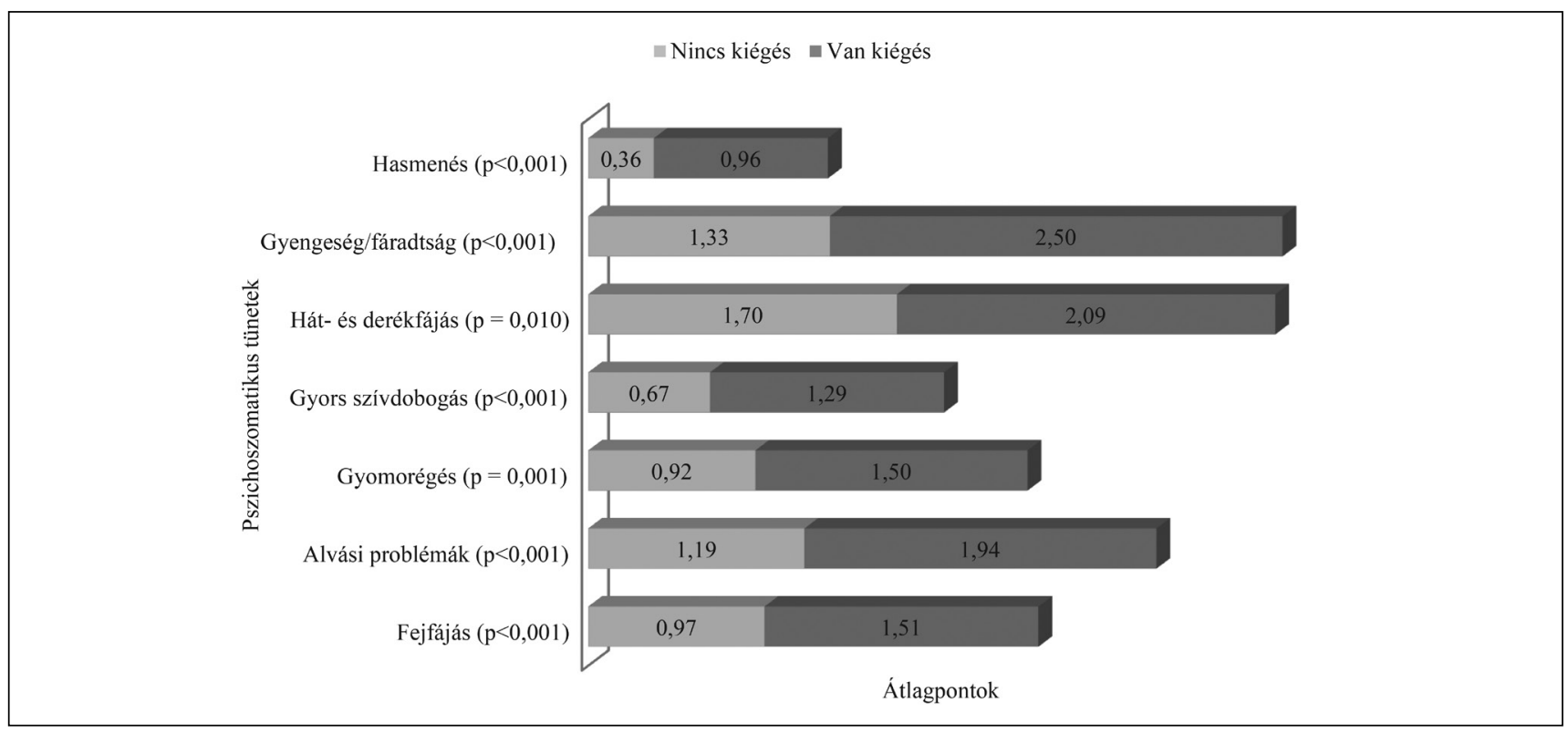

1. ábra

| A pszichoszomatikus tünetek átlagpontjainak összehasonlítása ( $\mathrm{N}=186)$

két csoport összehasonlításából származó eredményeket mutatom be.

A szociodemográfiai adatok közül egyedül a gyermekszám különbözik jelentős mértékben ( $\mathrm{p}=0,003 ; \mathrm{t}=$ 2,970) a két csoport között. A „nincs kiégés” csoport tagjainak átlag 1,84 gyermekük van $(S D=1,184$; minimum $=0 ;$ maximum $=5)$, míg a másik csoport tagjainak 1,33 $(\mathrm{SD}=1,086 ;$ minimum $=0$; maximum $=4)$.

A „nincs kiégés” csoport 48,3\%-a dolgozik az alapellátásban, 25,9\%-a a járóbeteg-ellátásban, 25,8\%-a a fekvőbeteg-ellátásban. A másik csoport tagjai esetében az arányok a következők (alap-járó-fekvő): 31,4\%-17,1\%$51,4 \%$. A különbség jelentős $(\mathrm{p}=0,002)$. A munkahelyi stressz szubjektív megítélésére a következő kérdést alkalmaztam: „Mennyire itéli stresszesnek a mindennapi munkáját?” ( 1 = egyáltalán nem; 4 = teljes mértékben). A kiégés által érintettek csoportjába tartozók szignifikánsan $(\mathrm{p}<0,001 ; \mathrm{U}=2528)$ stresszesebbnek ítélik meg mindennapi munkájukat, mint a másik csoport válaszadói. A többi munkahelyi tényező nem mutatott jelentős különbséget a két csoport között.

\section{Egészség vizsgálata}

Az egészség szubjektív önértékelését egy ötfokozatú Likert-skálával mértem ( 1 = nagyon rossz, $2=$ rossz, $3=$ elfogadható, 4 = jó; 5 = kiváló) [25]. A kiégettek és a nem kiégettek csoportja között szignifikáns különbség $(\mathrm{p}<0,001 ; \mathrm{U}=2133)$ mutatkozott ebben a paraméterben. A kiégettek csoportjába tartozók átlag 3,01-ra $(\mathrm{SD}=0,732)$, a nem kiégettek 3,69-ra $(\mathrm{SD}=0,703)$ értékelték saját egészségi állapotukat.

A saját kortársakhoz viszonyított egészséget a következő kérdéssel vizsgáltam: „Saját kortársaihoz hasonlitva hogyan minósiti saját egészségi állapotát?” (1 = sokkal rosszabb, 2 = rosszabb, 3 = ugyanolyan, 4 = jobb, $5=$ sokkal jobb) [26]. A két csoport között jelentős különbség $(\mathrm{p}<0,001 ; \mathrm{U}=2405)$ mutatkozott ennek a kérdésnek a megítélésében is. A kiégéssel küzdők átlag 2,97-ra $(\mathrm{SD}=0,900)$, a kiégés által nem érintettek 3,64-ra $(\mathrm{SD}=0,739)$ értékelték saját egészségüket a kortársaikhoz viszonyítva.

A pszichoszomatikus tünetek megjelenését egy hét kérdésből álló, 4 fokú Likert-skálával mértem $(0=$ soha, 1 = ritkán, 2 = időnként, 3 = gyakran) [27]; összesen 21 pontot lehetett elérni. Magasabb pontszám rosszabb pszichoszomatikus állapotot jelent. A „nincs kiégés” csoportba tartozók átlag 7,14 (SD = 3,265), a „van kiégés" csoportba tartozók 11,79 (SD = 3,671) pontot értek el ezen a skálán, a különbség szignifikáns $(\mathrm{p}<0,001$; $\mathrm{t}=-8,972)$. Mindegyik vizsgált pszichoszomatikus tünet szignifikánsan gyakrabban fordul elő a kiégettek csoportjában (1. ábra). Leggyakrabban hát- és derékfájás, gyengeség és fáradtság, valamint alvási problémák fordulnak elő pszichoszomatikus tünetként a megkérdezettek körében. $\mathrm{Ez}$ a három tünet a kiégéstől szenvedők több mint 40\%-át érinti (1. táblázat). A vizsgált minta esetében megállapítható, hogy a kiégés és a pszichoszomatikus tünetek között pozitív irányú erős korrelációs kapcsolat áll fenn $(\mathrm{p}<0,001 ; \mathrm{r}=0,650)$, vagyis minél kiégettebb valaki, annál gyakrabban jelentkezik pszichoszomatikus tünet.

A krónikus betegségeket vizsgálva elmondható, hogy a kiégés által nem érintettek 65,5\%-ának, a kiégés által érintettek 74,3\%-ának van legalább egy szervrendszert érintő krónikus megbetegedése, a különbség a két csoport között nem szignifikáns $(\mathrm{p}=0,211)$. Az első csoport válaszadói átlag $1,03(\mathrm{SD}=0,959)$, a kiégés által érintettek 1,53 ( $\mathrm{SD}=1,452)$ krónikus megbetegedést 
1. táblázat |A pszichoszomatikus tünetek gyakoriságának megoszlása a válaszadók körében $(\mathrm{N}=186)$

\begin{tabular}{llllll}
\hline \multirow{2}{*}{$\begin{array}{l}\text { Pszichoszomatikus } \\
\text { tünet }\end{array}$} & Csoportok & \multicolumn{4}{l}{ Elófordulás gyakorisága } \\
\cline { 2 - 6 } & & Soha & Ritkán & $\begin{array}{l}\text { Idón- } \\
\text { ként }\end{array}$ & $\begin{array}{l}\text { Gyak- } \\
\text { ran }\end{array}$ \\
\hline \multirow{2}{*}{ Fejfájás } & Nincs kiégés & $27,6 \%$ & $53,4 \%$ & $13,8 \%$ & $5,2 \%$ \\
\cline { 2 - 6 } & Van kiégés & $7,1 \%$ & $48,6 \%$ & $30,0 \%$ & $14,3 \%$ \\
\hline Alvási problémák & Nincs kiégés & $31,0 \%$ & $31,9 \%$ & $24,1 \%$ & $12,9 \%$ \\
\cline { 2 - 6 } & Van kiégés & $11,4 \%$ & $24,3 \%$ & $22,9 \%$ & $41,4 \%$ \\
\hline Gyomorégés & Nincs kiégés & $42,2 \%$ & $31,9 \%$ & $17,2 \%$ & $8,6 \%$ \\
\cline { 2 - 6 } & Van kiégés & $24,3 \%$ & $30,0 \%$ & $17,1 \%$ & $28,6 \%$ \\
\hline \multirow{2}{*}{$\begin{array}{l}\text { Gyors } \\
\text { szívdobogás }\end{array}$} & Nincs kiégés & $50,9 \%$ & $31,9 \%$ & $16,4 \%$ & $0,9 \%$ \\
\cline { 2 - 6 } & Van kiégés & $27,1 \%$ & $32,9 \%$ & $24,3 \%$ & $15,7 \%$ \\
\hline \multirow{2}{*}{ Hát- és derékfájás } & Nincs kiégés & $12,1 \%$ & $31,9 \%$ & $30,2 \%$ & $25,9 \%$ \\
\cline { 2 - 6 } & Van kiégés & $10,0 \%$ & $11,4 \%$ & $38,6 \%$ & $40,0 \%$ \\
\hline Gyengeség és & Nincs kiégés & $16,4 \%$ & $43,1 \%$ & $31,9 \%$ & $8,6 \%$ \\
\cline { 2 - 6 } fáradtság & Van kiégés & $0,0 \%$ & $11,4 \%$ & $27,1 \%$ & $61,4 \%$ \\
\hline \multirow{2}{*}{ Hasmenés } & Nincs kiégés & $68,1 \%$ & $28,4 \%$ & $2,6 \%$ & $0,9 \%$ \\
\cline { 2 - 6 } & Van kiégés & $44,3 \%$ & $27,1 \%$ & $17,1 \%$ & $11,4 \%$ \\
\hline
\end{tabular}

soroltak fel, a különbség szignifikáns $(\mathrm{p}=0,013 ; \mathrm{t}=$ $-2,533)$. A pszichiátriai, allergiás és daganatos megbetegedések aránya szignifikánsan magasabb a kiégettek csoportjában (2. ábra).

$\mathrm{Az}$ orvoshoz fordulás gyakoriságát az alábbi kérdéssel vizsgáltam: „Betegség esetén hányszor volt orvosnál az el- múlt 12 hónapban?” A ,nincs kiégés” csoportba tartozók átlag 1,01-szor $(S D=2,006$; minimum $=0$, maximum = 15), a másik csoportba tartozók 1,7-szer $(\mathrm{SD}=$ 3,061 ; minimum $=0$; maximum $=12$ ) kerestek fel orvost. A különbség a két csoport között nem jelentős ( $\mathrm{p}=$ $0,095 ; \mathrm{t}=-1,684)$. A táppénzes napok számát tekintve az első csoport válaszadói átlag 1,03 napot $(S D=5,009)$, a „van kiégés” csoport tagjai 3,53 napot $(S D=11,823)$ voltak táppénzen a kérdőív kitöltését megelőző egy évben. A különbség nem szignifikáns $(\mathrm{p}=0,096$; $\mathrm{t}=-1,682)$.

Külön kérdésben rátértem az altató- és nyugtatószedésre is. Mindkét gyógyszer szedésének gyakoriságában szignifikáns különbség van a két csoport között. Az altatót $(\mathrm{p}=0,032)$ és a nyugtatót $(\mathrm{p}=0,002)$ is jelentősen gyakrabban szedik azok a válaszadók, akiknél már jelentkezik a kiégés (2. táblázat).

A napi kávéfogyasztás gyakorisága nem különbözik jelentős mértékben a két csoportban $(\mathrm{p}=0,648)$. A válaszadók összességét nézve $17,2 \%$ soha nem fogyaszt kávét, 28,5\% naponta egyszer, 33,3\% naponta kétszer, $21 \%$ naponta többször fogyasztja. A dohányzás mértékében sem mutatkozott szignifikáns különbség a kiégéstől nem szenvedők és az azáltal érintettek csoportja között ( $\mathrm{p}=$ 0,921 ). A válaszadók egészét nézve $62,9 \%$ soha nem is dohányzott, 20,4\% korábban dohányzott, de már leszokott, 7\% (13 fó) dohányzik alkalmanként, 9,7\% (18 fó) pedig rendszeresen. A 31 fó dohányos 41,9\%-a 5 szál cigarettánál kevesebbet szív naponta, 12,9\% 5-10 szálat, 29\% 11-19 szálat, 16,1\% egy doboznál többet.

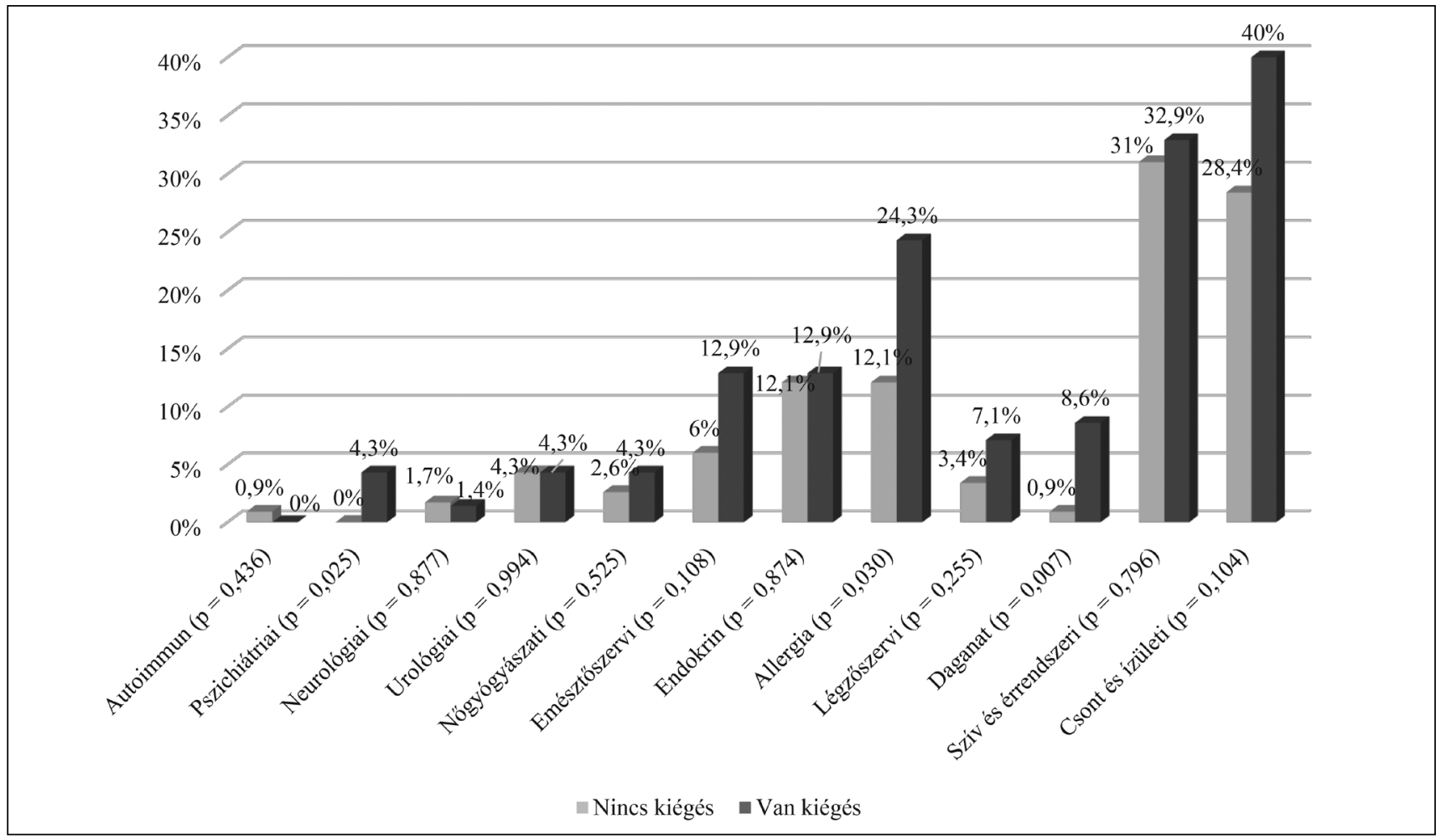


2. táblázat $\mid$ Az altató- és nyugtatószedés megoszlása $(\mathrm{N}=186)$

\begin{tabular}{llll}
\hline Szedés gyakorisága & Gyógyszer típusa & Nincs kiégés & Van kiégés \\
\hline \multirow{2}{*}{ Nem } & Altató & $90,5 \%$ & $77,1 \%$ \\
\cline { 2 - 4 } & Nyugtató & $88,8 \%$ & $68,6 \%$ \\
\hline \multirow{2}{*}{ Alkalmanként } & Altató & $7,8 \%$ & $15,7 \%$ \\
\cline { 2 - 4 } & Nyugtató & $9,5 \%$ & $22,9 \%$ \\
\hline \multirow{2}{*}{ Rendszeresen } & Altató & $1,7 \%$ & $7,2 \%$ \\
\cline { 2 - 4 } & Nyugtató & $1,7 \%$ & $8,5 \%$ \\
\hline
\end{tabular}

Az alkoholfogyasztás gyakoriságát elemezve szintén nem sikerült szignifikáns különbséget kimutatni a két csoport válaszai között $(\mathrm{p}=0,862)$. A válaszadók egészét nézve $1,6 \%$ fogyaszt naponta többször alkoholt, 9,7\% naponta egyszer, $18,3 \%$ hetente $1-2$-szer, $25,3 \%$ havonta párszor, $28 \%$ ritkábban, mint havonta, $17,2 \%$ pedig soha.

\section{Életérzés vizsgálata}

A jóllétet egy hét kérdésből álló, háromfokú Likert-skálával mértem ( $1=$ soha, 2 = ritkán, $3=$ gyakran) [28]. Négy kérdés vizsgálta a pozitív jóllétet, három a negatívat. A pozitív jólléti skálán magasabb pontszám jobb állapotot, míg a negatív jólléti skálán magasabb pontszám rosszabb állapotot jelent. A pozitív jólléti skálán a „nincs kiégés” csoportba tartozók átlag 10,88 (SD = 1,326) pontot, a másik csoportba tartozók $8,69(\mathrm{SD}=1,9)$ pontot értek el. A különbség szignifikáns $(\mathrm{p}<0,001$; $\mathrm{t}=8,491)$. A negatív jólléti skálán az első csoport tagjai átlag 4,72 (SD = 1,193) pontot, a „van kiégés” csoport tagjai 6,27 ( $\mathrm{SD}=1,25)$ pontot értek el. A különbség itt is szignifikáns $(\mathrm{p}<0,001 ; \mathrm{t}=-8,464)$. A megkérdezett orvosokról elmondható, hogy esetükben a kiégés és a pozitív jóllét között erôs, negatív irányú $(\mathrm{p}<0,001$; $\mathrm{r}=-0,670)$, a kiégés és a negatív jóllét között erős, pozitív irányú $(\mathrm{p}<0,001 ; \mathrm{r}=0,585)$ korrelációs kapcsolat mutatható ki. Vagyis minél kiégettebb egy válaszadó, pozitív jóllétének mértéke annál alacsonyabb, negatív jóllétének mértéke pedig annál magasabb.

Az élettel való elégedettséget egy öt kérdésből álló, hétfokozatú Likert-skálával mértem ( 1 = egyáltalán nem, 7 = teljes mértékben ért egyet az állítással) [29]. Maximum 35 pontot lehetett elérni. (A magasabb pontszám az élettel való nagyobb elégedettséget jelzi.) A „nincs kiégés" csoport tagjai átlag 25,03 (SD = 5,957) pontot, a „van kiégés” csoportba tartozók $18(\mathrm{SD}=6,852)$ pontot értek el ezen a skálán. A különbség a két csoport között jelentős $(\mathrm{p}<0,001 ; \mathrm{t}=7,359)$, vagyis a kiégés által érintettek élettel való elégedettsége szignifikánsan alacsonyabb, mint a kiégés által nem érintetteké. A kiégés és az élettel való elégedettség között erős, negatív irányú korrelációs kapcsolatot találtam $(\mathrm{p}<0,001 ; \mathrm{r}=-0,532)$, vagyis minél kiégettebb valaki, élettel való elégedettsége annál alacsonyabb.

\section{Alváskörülmények vizsgálata}

A napi alvásmennyiség tekintetében nincs szignifikáns különbség a „nincs kiégés” és a „van kiégés” csoport között $(\mathrm{p}=0,681)$. A válaszadók összességét nézve $15,1 \%$ alszik naponta 8 órát vagy annál többet; $81,7 \%$ 5-7 órát; $3,2 \%$ négy vagy annál kevesebb órát. Az alvás szubjektív értékelését a következő kérdéssel vizsgáltam: „Milyennek

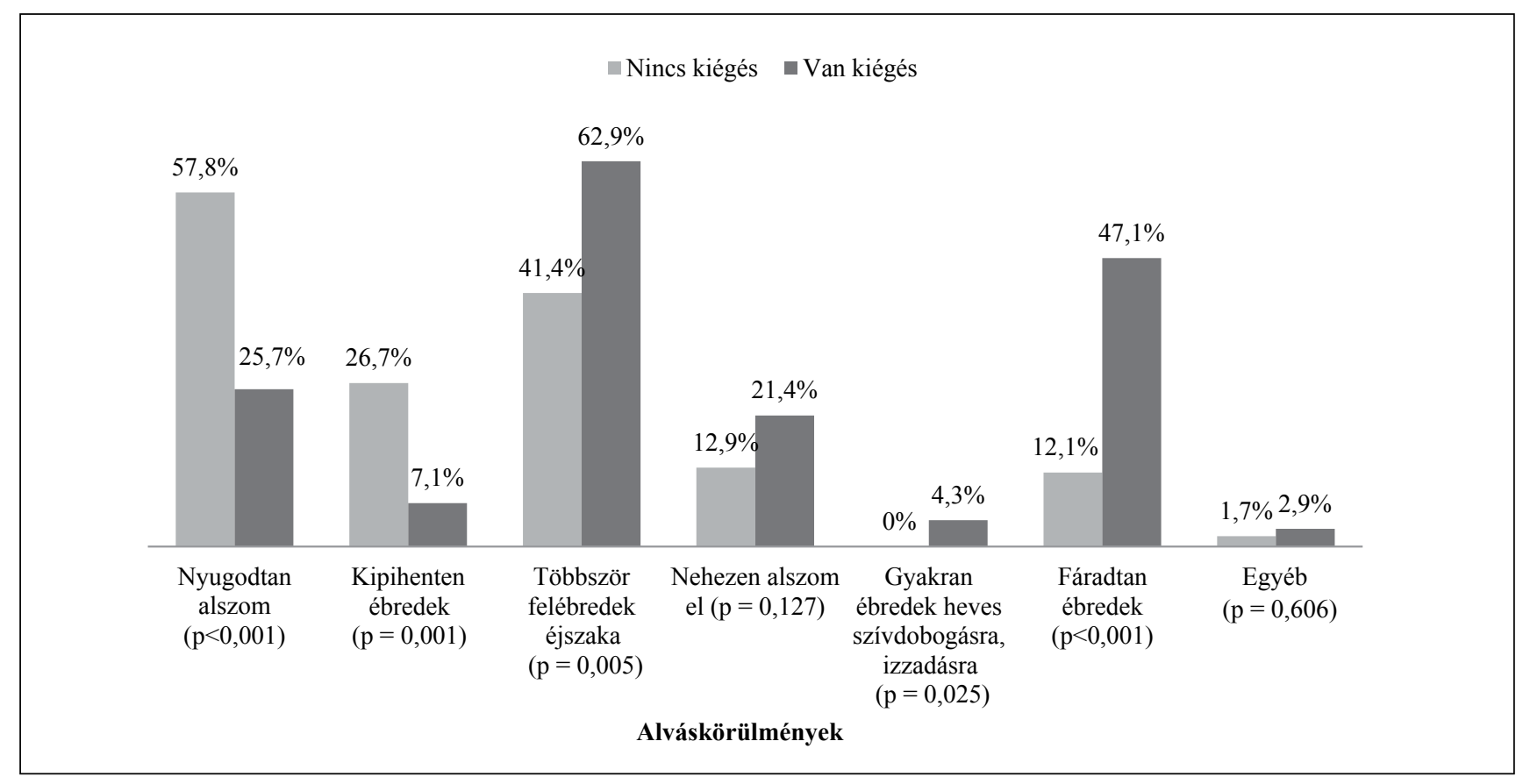


3. táblázat |A kiégés stresszorai a vizsgált orvosok körében $(\mathrm{N}=186)$

\begin{tabular}{|c|c|c|c|c|c|c|c|c|}
\hline \multirow{2}{*}{$\begin{array}{l}\begin{array}{l}\text { Függő } \\
\text { változó }\end{array} \\
\text { Kiégés }\end{array}$} & \multirow{2}{*}{$\begin{array}{l}\text { Magyarázó változó } \\
\text { Életkor }\end{array}$} & \multirow{2}{*}{$\begin{array}{c}\text { Standardizált } \\
\beta \\
-0,151\end{array}$} & \multicolumn{2}{|c|}{ 95\%-os konfidenciaintervallum } & $\mathrm{t}$ & \multirow{2}{*}{$\begin{array}{c}\mathrm{R}^{2} \\
0,023\end{array}$} & \multirow{2}{*}{$\begin{array}{c}\text { Korrigált } \mathrm{R}^{2} \\
0,017\end{array}$} & \multirow{2}{*}{$\begin{array}{c}\mathrm{p} \\
0,040\end{array}$} \\
\hline & & & $-0,028$ & $-0,001$ & $-2,068$ & & & \\
\hline & $\begin{array}{l}\text { Egészségügyben } \\
\text { eltöltöott évek }\end{array}$ & $-0,162$ & $-0,028$ & $-0,002$ & $-2,234$ & 0,026 & 0,021 & 0,027 \\
\hline & Gyermekszám & $-0,254$ & $-0,419$ & $-0,120$ & $-3,556$ & 0,064 & 0,059 & $<0,001$ \\
\hline & Havi túlóra & 0,050 & $-0,003$ & $-0,006$ & 0,677 & 0,003 & $-0,003$ & 0,499 \\
\hline & $\begin{array}{l}\text { Pszichoszomatikus } \\
\text { tüneti skála pontszáma }\end{array}$ & 0,650 & 0,164 & 0,231 & 11,59 & 0,422 & 0,419 & $<0,001$ \\
\hline & $\begin{array}{l}\text { Táppénzes napok } \\
\text { száma }\end{array}$ & 0,169 & 0,004 & 0,047 & 2,324 & 0,029 & 0,023 & 0,021 \\
\hline & $\begin{array}{l}\text { Élettel való } \\
\text { elégedettség }\end{array}$ & $-0,532$ & $-0,114$ & $-0,071$ & $-8,528$ & 0,283 & 0,279 & $<0,001$ \\
\hline & Pozitív jóllét & $-0,670$ & $-0,512$ & $-0,370$ & $-12,24$ & 0,449 & 0,446 & $<0,001$ \\
\hline & Negatív jóllét & 0,585 & 0,407 & 0,612 & 9,773 & 0,342 & 0,338 & $<0,001$ \\
\hline
\end{tabular}

itéli meg alvását?” ( 1 = nagyon rossz; 2 = rossz; 3 = jó; 4 = kiváló). Azon csoport tagjai, akiknél nem jelentkeznek a kiégés tünetei, szignifikánsan jobbnak ítélték meg alvásukat ( $\mathrm{p}=0,002 ; \mathrm{U}=3052)$, mint a kiégés által érintettek.

Az alváskörülményeket egy hat választási lehetőséget, valamint az egyéb megjelölésének lehetőségét felkínáló kérdéssel kutattam. A „nincs kiégés” csoport tagjaira jelentősen gyakrabban jellemző a nyugodt alvás és a kipihent ébredés; míg a „van kiégés” csoport tagjainál a többszöri felébredés, heves szívdobogás és fáradt ébredés fordul elő szignifikánsan gyakrabban (3. ábra). Egyéb válaszlehetőséget négy fő jelölt meg: CPAP-t használ; felébredés után nehéz visszaalvás; hajnali ébredés; nyugtalan láb szindróma.

Lineárisregresszió-analízissel elemeztem a kiégés stresszorait a felmérésben részt vevő orvosok körében. A kiégésben a havi túlóra mennyisége nem játszik szerepet. A legerősebb magyarázóerővel a pszichoszomatikus tünetek, az élettel való elégedettség, a pozitív és a negatív jóllét rendelkezik. A pszichoszomatikus tünetek a kiégés varianciájának 41,9\%-át, az élettel való elégedettség $27,9 \%$-át, a pozitív jóllét $44,6 \%$-át, a negatív jóllét pedig 33,8\%-át magyarázza. A kiégéshez az életkor, az egészségügyben eltöltött évek, a gyermekek és a táppénzes napok száma is szignifikánsan hozzájárulnak (3. táblázat).

\section{Megbeszélés}

Országos, nem reprezentatív felmérésemben az orvosok kiégését kívántam feltárni összefüggésben az egészséggel, pszichoszomatikus tünetekkel, életérzéssel, alváskörülményekkel. Az eredmények rávilágítottak arra, hogy a vizsgálatban szereplő orvosok 37,6\%-át érinti a kiégés, amely eredmény hasonló más hazai, a Maslach Burnout Inventory alkalmazásával készített felmérésekhez

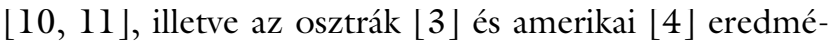
nyekhez. Leginkább a fiatalabb, pályája elején lévő korosztályt érinti ez a jelenség, és a fekvőbeteg-ellátásban dolgozók körében fordul elő gyakrabban. A fiatal orvosok kiégettségét több kutatás is bizonyította már $[10,12,13]$, illetve a fekvőbeteg-ellátásban végzett munka szintén oki tényezóként szerepelt [12]. Több gyermek a kiégés protektív tényezőjének bizonyult a megkérdezettek körében, hasonlóan, mint Györffy és Girasek kutatásában [12]. A fiatalabb orvosok kiégettsége ezzel is magyarázható, mivel ők még életkorukból adódóan kevesebb gyermeket nevelnek, így a gyermekek protektív hatása a burnouttal szemben esetükben nem vagy csak alig érvényesül.

Bebizonyosodott a kiégés és a munkahelyi stressz közötti szoros kapcsolat is, alátámasztva ezzel több kutató eredményét [2, 7, 10]. Azok a válaszadók, akiknek kiégéspontszáma alacsonyabb, jelentósen jobbnak ítélik meg saját egészségüket, és kortársaikhoz hasonlítva is jobbnak értékelik azt, mint a magas kiégéspontszámmal rendelkezők, akárcsak a korábbi felmérésekben [6, 10].

A kiégés szoros összefüggést mutatott a pszichoszomatikus tünetképzéssel is, mindegyik vizsgált tünet jelentősen gyakrabban fordult elő a kiégés által érintettek csoportjában. Hát- és derékfájás, gyengeség és fáradtság, valamint alvási problémák fordultak elő leggyakrabban pszichoszomatikus tünetként a megkérdezettek körében. A kiégés és a pszichoszomatikus tünetek gyakorisága közötti összefüggést korábbi felmérésekben is bizonyították már, Papp és Túry kutatásában is a hát- és derékfájás, valamint a fáradtság jelentkezett leggyakoribb pszichoszomatikus tünetként a kiégéssel összefüggésben [13].

A kiégés mértéke a krónikus betegségek számával is szoros összefüggést mutatott. A pszichiátriai, allergiás és daganatos betegségek jelentősen gyakrabban fordulnak elő a kiégéssel küzdő válaszadóknál, valamint ők szednek 
gyakrabban altatót és nyugtatót is. A burnout megléte a pozitív jóllét érzetét csökkenti, a negatív jóllét érzetét pedig növeli, következményesen az élettel való elégedettség mértéke is jelentősen csökkent, valamint alvással kapcsolatos problémák is gyakrabban jelentkeznek. Ádám és mtsai pánikbetegség és allergiás megbetegedések, valamint alvászavar kialakulását hozták összefüggésbe a kiégéssel [10]. Jelen felmérésben az orvoshoz fordulás gyakorisága és a táppénzes napok száma nem függ össze szignifikánsan a kiégés mértékével, az azonban megállapítható, hogy a kiégett válaszadók 3,5-szer anynyit voltak táppénzen, mint a kiégés által nem érintett kollégáik. A kávé-, dohány- és alkoholfogyasztás sem függ össze jelen esetben a kiégettség mértékével.

A kiégés prevenciója az egészségügy egyik legnagyobb kihívása, nem csupán az orvosok, hanem minden, egészségügyben dolgozó számára hangsúlyos kérdéssé kell, hogy váljon. A megelőzésre, pszichés állapot javítására több lehetséges megoldás is létezik. Linzer és mtsai szerint az orvosok kiégésének megelőzésében több tényező is szerepet játszhat: teammunka, munkakörnyezet feletti magasabb ellenőrzés, részmunkaidős foglalkoztatás [5]. Pines és Aronson is a munkahelyi társas támogatást és a pozitív légkörú munkahelyet hangsúlyozza a kiégés prevenciója szempontjából [19]. Léteznek stressztünetek enyhítésére szolgáló módszerek is, amelyek hozzájárulhatnak a kiégés csökkenéséhez (például: viselkedésterápia, meditáció, relaxáció, bio-feed-back-tréning, testmozgás növelése) [30]. Az érzelmi megterhelés csökkentése szempontjából lényeges a „megfelelő távolság beállitása a beteg felé”, vagyis fontos a távolságtartó attitűd és higgadtság, amely hozzájárul az objektivitás megőrzéséhez, ugyanakkor az orvos megértő kapcsolatban marad betegével [31].

A hazai egészségügyi dolgozók számára hatékony módszer lehet a kiégés csökkentésében a pozitív pszichológiai módszereken alapuló kiégésmegelőző tréning [12]. Egészségügyi szakdolgozók körében már korábban is zajlottak a kiégés szempontjából javulást hozó beavatkozások [21, 23], amely az orvosok körében is hatékony lehet.

Anyagi támogatás: A kutatás és a közlemény megírása anyagi támogatásban nem részesült.

Szerzôi munkamegosztás: A cikk végleges változatát a szerző elolvasta és jóváhagyta.

Érdekeltségek: A szerzőnek nincsenek érdekeltségei.

\section{Köszönetnyilvánítás}

Ezúton szeretném köszönetemet kifejezni a WebDoki Hírlevél Szerkesztőségének és a Magyar Orvosok Szövetségének, hogy közremüködtek kérdőívem terjesztésében.

\section{Irodalom}

[1] Freudenberger, H. J.: Staff burn-out. J. Soc. Issues, 1974, 30(1), 159-165.

[2] Fekete, S.: Risks of helping professions. Helfer syndrome and burnout phenomenon. [Segítő foglalkozások kockázatai. Helferszindróma és burnout jelenség.] Psychiatr. Hung., 1991, 6(1), 17-29. [Hungarian]

[3] Fuchs, S., Mesenholl-Strebler, E., Endler, P. C.: Physician burnout in general practitioners reflections upon prevention and treatment. Int. J. Communication, 2011, 2(5), 53-60.

[4] Shanafelt, T. D., Boone, S., Tan, L., et al.: Burnout and satisfaction with work-life balance among US physicians relative to the general US population. Arch. Intern. Med., 2012, 172(18), 1377-1385.

[5] Linzer, M., Levine, R., Meltzer, D., et al.: 10 bold steps to prevent burnout in general internal medicine. J. Gen. Intern. Med., $2014,29(1), 18-20$.

[6] Suñer-Soler, R., Grau-Martín, A., Font-Mayolas, S., et al.: Burnout and quality of life among Spanish healthcare personnel. J. Psychiatr. Ment. Health Nurs., 2013, 20(4), 305-313.

[7] Tziner, A., Rabenu, E., Radomski, R., et al.: Work stress and turnover intentions among hospital physicians: The mediating role of burnout and work satisfaction. J. Work Organ. Psychology, 2015, 31(3), 207-213.

[8] Dewa, C. S., Loong, D., Bonato, S., et al:: How does burnout affect physician productivity? A systematic literature review. BMC Health Serv. Res., 2014, 14(1), 325.

[9] Sablik, Z., Samborska-Sablik, A., Drożdz, J.: Universality of physicians' burnout syndrome as a result of experiencing difficulty in relationship with patients. Arch. Med. Sci., 2013, 9(3), 398403.

[10] Ádám, Sz., Györffy, Zs., Csoboth, Cs.: Burnout syndrome in the medical profession. [Kiégés (burnout) szindróma az orvosi hivatásban.] Hippocrates, 2006, 8(2), 113-117. [Hungarian]

[11] Ádám, Sz., Torzsa, P., Györffy, Zs., et al.: Frequent occurance of level burnout among general practitioners and residents. [Gyakori a magas fokú kiégés a háziorvosok és háziorvosi rezidensek körében.] Orv. Hetil., 2009, 150(7), 317-323. [Hungarian]

[12] Györffy, Zs., Girasek, E.: Burnout among Hungarian physicians. Who are the most jeopardized? [Kiégés a magyarországi orvosok körében. Kik a legveszélyeztetettebbek?] Orv. Hetil., 2015, 156(14), 564-570. [Hungarian]

[13] Papp, Sz., Túry, F.: Future perspectives and health conditions of recently graduated physicians. [A pályakezdő orvosok jövóképe és egészségi állapota.] LAM, 2010, 20(6-7), 423-429. [Hungarian]

[14] Bognár, T., Kolosai, N., Hegedüs, K., et al.: 'To hold the hand of the dyin!' In-depth interviews with doctors regarding the difficulties during caring for dying people. [ „Kellene, aki megfogná a haldokló kezét!" Orvosokkal készült mélyinterjúk elemzése a haldoklógondozás nehézségeiről.] LAM, 2001, 11(2), 154-162. [Hungarian]

[15] Linzer, M., Manwell, L. B., Williams, E. S., et al.: Working conditions in primary care: physician reactions and care quality. Ann. Intern. Med., 2009, 151(1), 28-36.

[16] Prins, J. T., van der Heijden, F. M., Hoekstra-Weebers, J. E., et al.: Burnout, engagement and resident physicians' self-reported errors. Psychol. Health Med., 2009, 14(6), 654-666.

[17] Maslach, C., Jackson, S. E.: Maslach Burnout Inventory. 2nd ed. Consulting Psychologists Press, Palo Alto, 1986.

[18] Kovács, M.: The phenomenon of burnout in view of the Hungarian and international literature. [A kiégés jelensége a kutatási eredmények tükrében.] LAM, 2006, 16(11), 981-987. [Hungarian]

[19] Pines, A. M., Aronson, E.: Burnout: from Tedium to Personal Growth. The Free Press, New York City, 1981, 17-20. 
[20] Irinyi, T., Németh, A.: The impact of unfavourable external factors on the emotional wellbeing of paramedical professionals. Practising nursing in Hungary today is a one-way ticket to mental and physical burnout! [Az egészségügyet ért kedvezőtlen külső hatások következménye a szakdolgozók lelki egészségére. A nővér hivatásának gyakorlása Magyarországon, ma egyenes út a szellemi és fizikai kiégéshez!] Nővér, 2010, 23(5), 23-31. [Hungarian]

[21] Irinyi, T., Németh, A.: A burnout health assessment and the results of the following interventions. [Egy burnout egészségfelmérés és az azt követő beavatkozás eredményei.] IME, 2011, 10(1), 25-28. [Hungarian]

[22] Németh, A., Irinyi, T.: Comparison of somatic and psychological health of health care workers in Csongrád County between the years of 2008 and 2012. [Egészségügyi szakdolgozók testi és lelki egészségének összehasonlítása Csongrád megyében: 2008 2012.] Nôvér, 2012, 25(4), 28-35. [Hungarian]

[23] Németh, A., Bársonyné Kis K., Lantos, K.: Effects of stress management and recreational training on employees in public health. [Stresszkezeló és regenerációs program hatása egészségügyi munkavállalókra.] IME, 2015, 14(1), 27-30. [Hungarian]

[24] Ofori-Attah, B., Németh, A.: The effects of night shifts on nurses. [Éjszakai múszak hatásai az ápolókra.] Nővér, 2015, 28(4), 3-9. [Hungarian]

[25] Kopp, M., Skrabski, Á., Réthelyi, J., et al.: Self related health, subjective social status and middle-aged mortality in a changing society. Behav. Med., 2004, 30(2), 65-72.
[26] Kopp, M., Skrabski, Á.: Psychological and social background fac tors of having children in the Hungarian population. [A gyermekvállalás pszichológiai és szociális háttértényezői a magyar népesség körében.] Demográfia, 2003, 46(4), 383-395. [Hungarian]

[27] Pikó, B., Barabás, K., Boda, K.: Frequency of common psychosomatic symptoms and its infuence on self-perceived health in a Hungarian student population. Eur. J. Public Health, 1997, $7(3), 243-247$

[28] Bradburn, N. M.: The structure of Psychological Well-Being. Aldine Publishing, Chicago, 1969.

[29] Diener, E., Emmons, R. A., Larsen, R. J., et al.: The satisfaction with life scale. J. Pers. Assess., 1985, 49(1), 71-75.

[30] Regehr, C., Glancy, D., Pitts, A., et al.: Interventions to reduce the consequences of stress in physicians: a review and metaanalysis. J. Nerv. Ment. Dis., 2014, 202(5), 353-359.

[31] Major, J., Ress, K., Hulesch, B., et al.: Burnout phenomenon in the medical profession. [A kiégés jelensége az orvosi hivatásban.] LAM, 2006, 16(4), 367-373. [Hungarian]

(Németh Anikó Dr., Szeged, Temesvári krt. 31., 6726 e-mail: nemetha@etszk.u-szeged.hu)

\title{
MEGHÍVó
}

\section{A Szent János Kórház és Észak-budai Egyesített Kórházak Tudományos Bizottsága tisztelettel meghívja az érdeklődőket a következő tudományos ülésére.}

\section{Téma: IVF - Új trendek az asszisztált reprodukcióban}

\author{
Időpont: 2016. április 28. (csütörtök) 14.00 óra
}

Helyszín: Szent János Kórház Auditóriuma - 1125 Budapest, Diós árok 1-3.

\section{Üléselnök: Prof. Dr. Jánosi András}

\section{Program:}

Dr. Konc János: Uliprisztál-acetát (Esmya) - Myoma kezelése és az asszisztált reprodukció

Prof. Dr. Cseh Sándor (Szent István Egyetem, ÁOK, Szaporodásbiológiai Szülészeti Tanszék):

Asszisztált reprodukciós technikák alkalmazása a humán és az állatgyógyászatban

15 perc

Dr. Kanyó Katalin, Kriston Rita, Blahó Krisztina, Dr. Konc János:

Preimplantációs genetikai vizsgálatok új lehetöségei

Dr. Zeke József, Dr. Stephen G. Somkuti (Abington, USA), Dr. Konc János:

Lehetőségek és korlátok az IVF területén napjaikban

Dr. Szücs Zoltán: Ovarium hyperstimulációs szindróma (OHSS) mindennapi gyakorlatunkban

Koós Ágnes, Dr. Kopa Zsolt (SE Urológiai Klinika), Dr. Kanyó Katalin:

Mikro TESE, laboratóriumi módszerek a spermium kinyerésére hereszövetböl - azoospermiás eseteknél

15 perc

Dr. Szentiványi Zoltán: Zika-láz és a meddőség kezelésének összefüggései

\section{BÜFÉ}

Minden érdeklődőt szeretettel várunk! 